\title{
MENINGKATKAN PENGUASAAN KONSEP BILANGAN ANAK USIA DINI MELALUI MEDIA PUZZEL
}

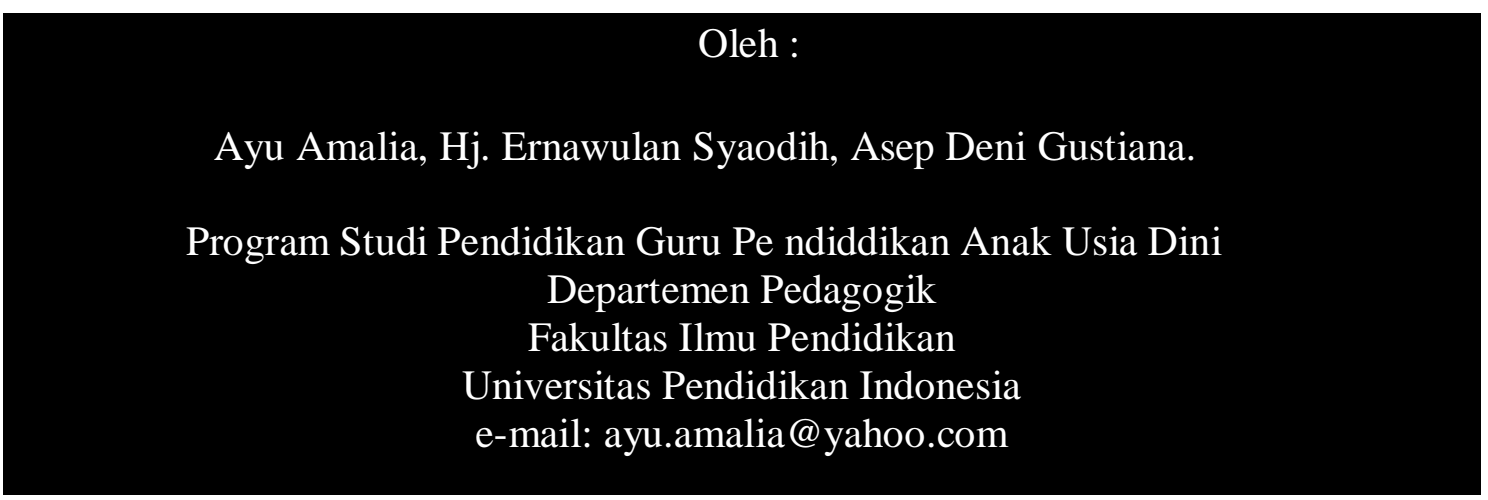

Abstrak: Penelitian ini dilatarbelakangi oleh rendahnya kemampuan penguasaan konsep bilangan sederhana anak usia dini di kelompok A Abu Bakar Sidiq Cimahi. Permasalahan yang muncul terkait penguasaan konsep bilangan sederhana diantaranya (1) mengenai pemahaman konsep matematika, contohnya anak hanya mampu menyebutkan bilangannya saja tanpa memahami bagaiman lambang bilangan tersebut. (2) anak belum mampu mengurutkan bilangan angka. Untuk mengatasi masalah tersebut peneliti menerapkan media pembelajaran berupa alat permainan edukatif puzzel. Penelitian ini dilakukan di kelompok A Abu Bakar Sidiq RA Al-Kautsar Cimahi, dengan jumlah subjek 22 anak. Metode yang digunakan adalah Penelitian Tindakan Kelas (PTK) dengan model Kemmis yang terdiri dari empat tahap yaitu: 1) perencanaan. 2) pelaksanaan, 3) observasi, 4) refleksi. Instrument penelitian yang digunakan berupa lembar observasi kemampuan penguasaan konsep bilangan sederhana, catatan lapangan, dan pedoman wawancara. Analisis data pada kemampuan penguasaan konsep bilangan sederhana melalui penggunaan media pembelajaran APE puzzel ini mengacu pada kurikulum 2013 yang dijabarkan pada kisi-kisi instrument. Penelitian ini dilakukan dengan 2 siklus yang terdiri dari 2 pertemuan. Hasil kemampuan penguasaan konsep bilangan sederhana terdiri dari 8 indikator dengan kategori baik saat pra-siklus 0\%, akhir siklus I 9\% menjadi 77\% di akhir siklus II. Kategori cukup 27\% saat pra-siklus, dan 68\% akhir siklus I menjadi $23 \%$ pada siklus II. Kategori Kurang $73 \%$ pra-siklus, dan 23\% pada akhir siklus I menjadi 0\% saat akhir siklus II. Dengan begitu dapat dikategorikan bahwa penerapan penggunaan media pembelajaran APE puzzel dapat meningkatkan kemampuan penguasaan konsep bilangan sederhana anak usia dini di kelompok A Abu Bakar Sidiq RA Al-Kautsar Cimahi.

\section{Kata Kunci: Kemampuan Penguasaan Konsep Bilangan, Media Pembelajaran Puzzel}




\begin{abstract}
This research is motivated by the low ability to mastery of simple numbers concept for early childhood in group of A Abu Bakar Sidiq Cimahi. The Problems that arise related to mastery of simple numbers concept including : (1) about understanding mathematical concepts, for example children are only able to mention the numbers without understanding how the symbols are. (2) children have not been able to sort numbers. To overcome these problems, researchers applied learning media in the form of educative games tool puzzle. This research was conducted in group A Abu Bakar Sidiq RA Al-Kautsar Cimahi, with the number of subjects 22 children. The method used is Classroom Action Research (CAR) with the Kemmis model which consists of four stages, i.e: 1) planning. 2) implementation, 3) observation, 4) reflection. The research instrument used in the form of an observation sheet the ability to control simple number concepts, field notes, and interview guidelines. Data analysis on the ability to control simple number concepts through learning media the APE puzzle refers to 2013 curriculums which is elaborated on the instrument grid. This research was conducted in 2 cycles consisting of 2 meetings. The results of ability to control simple number concepts consist of 8 indicators with a good category at the precycle $0 \%$, the end of the first cycle $9 \%$ to $77 \%$ at the end of the second cycle. Fair category is $27 \%$ in the pre-cycle, and $68 \%$ at the end of the first cycle to $23 \%$ in the second cycle. Less category $73 \%$ pre-cycle, and $23 \%$ at the end of the first cycle to $0 \%$ at the end of the second cycle. In this way, it can be categorized that the application of learning media using APE puzzle can improve the ability to control simple number concepts in early childhood in group A, Abu Bakar Sidiq RA Al-Kautsar Cimahi.
\end{abstract}

Keywords : The Ability of Simple Number Concept, Learning Media of Puzzle

\section{PENDAHULUAN}

Anak usia dini adalah sosok individu yang memiliki potensi yang harus dikembangkan. Pada saat ini tumbuh kembang anak berkembang sangat pesat, sehingga dapat dikatakan pada masa ini ialah masa keemasan (Golden Age) dimana masa ini anak dapat merekam apa yang didengar dan meniru apa yang dilihat sehingga sering kali diberi sebutan sebagai peniru ulung. Tumbuh kembangnya diusahakan terstimulasi secara optimal, agar terwujudnya individu yang berkualitas. Salah satu upaya dalam menstimulasi tumbuh kembang anak yaitu melalui jalur pendidikan. Pendidikan sangat penting karena anak usia dini memerlukan bimbingan dan stimulasi yang tepat untuk bisa tumbuh dan berkembang secara optimal. Undang-undang Nomer 20 Tahun 2003 tentang Sistem Pendidikan Nasional menyatakan pendidikan anak usia dini adalah suatu upaya pembinaan yang ditujukan kepada anak sejak lahir sampai dengan usia 6 tahun yang dilakukan melalui pemberian stimulus pendidikan agar anak memiliki kesiapan dalam memasuki pendidikan lebih lanjut. Pendidikan Anak Usia Dini (PAUD) adalah suatu 
upaya pembinaan yang ditunjukan kepada anak sejak lahir sampai dengan usia enam tahun yang dilakukan melalui pemberian rangsangan pendidikan untuk membantu pertumbuhan dan perkembangan jasmani dan rohani agar anak memiliki kesiapan dalam memasuki pendidikan lebih lanjut (Masitoh, dkk, 2005, hlm.48). PAUD merupakan lembaga pendidikan pertama yang dijalani oleh anak, sehingga dapat mempengaruhi pengalaman belajar anak ke tingkat selanjutnya. PAUD bertujuan untuk mengembangkan berbagai potensi anak sejak dini sebagai bekal hidup dan menyesuaikan diri dengan lingkungannya. Pemberian stimulus disesuaikan dengan tahapan usia dan kemampuan anak, agar tercapainya standar kompetensi yang harus dilalui anak. Di sekolah dilakukan pembekalan kehidupan dalam bentuk pembelajaran.

Peraturan Mentri Pendidikan Nasional Nomer 58 Tahun 2009 menyatakan bahwa penyelenggaraan PAUD terdiri dari dua jalur, yaitu jalur pendidikan formal dan non formal. Penyelenggaraan PAUD jalur pendidikan formal berbentuk Taman Kanak-kanak (TK) atau Raudhatul Athfal (RA) sedangkan penyelenggaraan PAUD jalur pendidikan non formal berbentuk Taman Penitipan Anak (TPA) dan Kelompok Bermain (KB).

PAUD khususnya Taman Kanakkanak adalah pendidikan yang diselenggarakan dengan tujuan untuk memfasilitasi pertumbuhan dan perkembangan anak secara menyeluruh atau menekankan pada pengembangan seluruh aspek kepribadian anak (Masitoh, dkk, 2005, hlm. 52). Pembelajaran meliputi enam aspek kompetensi yang akan dikembangkan, diantaranya aspek pengembangan nilai agama dan moral, aspek pengembangan fisik motorik, aspek pengembangan kognitif, aspek pengembangan sosial emosional, aspek pengembangan bahasa dan aspek pengembangan seni. Salah satu aspek penting yang perlu dikembangkan dalam pembelajaran anak usia dini adalah perkembangan kognitif. Dengan berkembangnya pengembangan kognitif maka anak usia dini mampu mengembangkan kemampuan persepsi, ingatan, berpikir, dan pemahaman terhadap bilangan sederhana, dan dapat melakukan penalaran dalam memecahkan suatu masalah.

Kegiatan belajar mengajar yang menekankan pada kegiatan belajar agar terjadi proses belajar (Ruhimat, T. dkk, 2013, hlm. 32). Pembelajaran menekankan pada proses, karena dengan proses yang baik maka hasilnyapun akan sesuai dengan apa yang diharapkan. Dalam berproses anak mencoba hal baru yang akan menghasilkan pengalaman belajar. Dengan pengalaman belajar maka anak akan mendapatkan kesiapan dan kematangan sikap dalam bertindak.

Menurut Bruner (Khadijah 2016, hlm. 56) anak-anak belajar dari konkret ke abstrak. Dalam pembelajarannya dibutuhkan benda yang nyata dan riil untuk menunjang 
pemahaman anak, dengan begitu anak dengan mudah akan mendapatkan pemahaman konsep simbol atau lambang bilangan. Kognitif adalah suatu proses berfikir yang berhubungan dengan tingkat kecerdasan.

Berfikir kognitif merupakan kompetensi yang dibutuhkan dalam menjalankan kehidupan sehari-hari agar dapat bertahan hidup. Misalnya dengan berfikir kognitif kita dapat memecahkan masalah yang dihadapi, mencari jalan keluar dari apa yang dialami, dan tetap bertahan dalam keadaan apapun.

Adapun pembelajaran yang termasuk dalam aspek pengembangan kognitif diantaranya adalah memahami konsep bilangan sederhana. Konsep bilangan merupakan dasar pengembangan kemampuan matematika maupun kesiapan untuk mengikuti pendidikan dasar (Kustini, 2010, hlm. 34). Dengan memahami konsep bilangan sederhana maka terbukalah pemahaman matematika ketingkat selanjutnya. Konsep yang dipahami anak sejalan dengan bertambahnya pengalaman yang diamati anak. Semakin banyaknya pengalaman yang miliki anak maka semakin banyak pula konsep yang dipahaminya.

Berdasarkan data di lapangan mengenai kemampuan menguasai konsep bilangan di RA Al-Kautsar, denan jumlah anak 22 terdapat 16 anak yang masih belum paham mengenai konsep bilangan sederhana, dan 6 anak yang masih memerlukan bantuan, sedangkan anak yang sudah paham mengenai konsep bilangan sederhana belum ada anak. Hal tersebut diketahui menurut hasil observasi serta wawancara kepada guru di kelas.

Metode belajar sambil bermain akan menimbulkan motivasi belajar sehingga konsep matematika dibentuk melalui pengalaman langsung. Adapun upaya dalam menambah pengalaman anak yaitu dengan menggunakan pembelajaran yang menarik. Pembelajaran yang dimaksudkan di sini adalah penggunaan media pembelajaran berupa alat permainan edukatif puzzle.

Puzzle digunakan dalam penelitian ini karena dengan adanya puzzle akan dapat menarik minat anak. Puzzle dibuat dengan berwarna. Pembelajaran dilakukan dengan cara belajar seraya bermain atau bermain sambil belajar. Dengan begitu maka pengetahuan atau kemampuan anak dapat berkembang melalui pengalaman belajar secara langsung. Penggunaan media pembelajaran APE puzzle pun cukup mudah yaitu dengan menghubungkan atau menjodohkan antara lambang bilangan dengan jumlah benda yang sama, lalu mengurutkan bilanganbilangan tersebut. Untuk mengetahui lebih jauh dari kemampuan anak maka penggunaan APE puzzel bisa di pasangkan secara acak antara lambang bilangan dan jumlah benda, sehingga kita dapat melihat kemampuan anak dalam memcahkan masalah tersebut. 


\begin{abstract}
Penelitian ini dilatar belakangi
oleh rendahnya kemampuan penguasaan konsep bilangan sederhana, hal ini dilihat dari kurang aktifnya anak saat kegiatan belajar, pembelajaran yang dilakukan kurang alat peraga sehingga pembelajaran yang berlangsung berjalan secara monoton dan kurang memberingan pengalaman belajar yang berarti.

Berdasarkan permasalahan di atas, maka peneliti ingin meningkatkan hasil belajar dalam aspek kognitif dengan melakukan Penelitian Tindakan Kelas (PTK) dengan judul "Meningkatkan Penguasaan Konsep Bilangan Anak Usia Dini Melalui Penggunaan Media Puzzel”.
\end{abstract}

\section{METODE PENELITIAN}

Metode yang digunakan dalam penelitian ini adalah metode Penelitian Tindakan Kelas. Dimana penelitian tindakan kelas ini merupakan penelitian yang dilakukan oleh guru kelasnya sendiri melalui refleksi diri dengan tujuan untuk memperbaiki kinerjanya sehingga hasil belajar siswa meningkat (Aqil, dkk, 2009, hlm.3)

Penelitian ini bertujuan untuk mengembangkan metode kerja yang paling efisien. Penelitian tindakan kelas ini juga dimaksudkan sebgai suatu proses yang dilalui oleh perorangan atau kelompok yang menghendaki perubahan dalam situasi tertentu untuk menguji prosedur yang diperkirakan akan menghasilkan perubahan tersebut dan kemudian, setelah sampai padan tahap kesimpulan yang dapat dipertanggungjawabnkan, melaksanakan prosedur ini (Sugiono, 2010, hlm.9).

Dalam penelitian ini mengacu pada prosedur Peneitian Tindakan Kelas dari Kemmis dan Mc Tagart dalam (Sujati, 2000 hlm.23), yang dalam kegiatan menggunakan siklus sistem spiral. Masing-masing siklus terdiri dari empat komponen pokok yaitu perencanaan, pelaksanaan tindakan, observasi, dan refleksi. Subjek dalam penelitian ini yaitu kelompok A Abu Bakar Sidiq RA Al Kautsar yang jumlahnya 22 anak. Metode pengumpulan data menggunakan metode wawabcara, observasi dan catatan lapangan.

\section{HASIL DAN PEMBAHASAN}

Berdasarkan temuan lapangan pada penguasaan konsep bilangan anak sangatlah beragam, hal ini dapat terus berkembang, sehingga pembelajaran yang diterimanya menjadi optimal. Pada bagian ini akan dibahas mengenai temuan hasil penelitian yang telah dikemukakam sebelumnya, mengenai meningkatkan penguasaan konsep bilangan melalui penggunaan media puzzel. Meliputi 1) kondisi awal penguasaan konsep bilangan anak usia dini kelompok A Abu Bakar Sidiq, 2) pelaksanaan pembelajaran penguasaan konsep bilangan melalui penggunaan media puzzel, 3) peningkatan penguasaan konsep bilangan melalui media puzzel. 
1. Kondisi Awal Penguasaan Konsep Bilangan Anak Usia Dini Kelompok A Abu Bakar Sidiq.

Kondisi objek berdasarkan hasil observasi menunjukan bahwa kemampuan penguasaan konsep bilangan anak kelompok A Abu Bakar Sidiq sangat beragam. Sebelum tindakan dilakukan, peneliti mengobservasi kemampuan penguasaan konsep bilangan melalui delapan sub indikator sesuai dengan kurikulum yang berlaku yaitu anak dapat menyebutkan bilangan 1-5, anak dapat menyebutkan bilangan 15 secara acak, anak dapat menyebutkan bilangan 6-10, anak dapat menyebutkan bilangan 6-10 secara acak, anak dapat mengurutkan bilangan 1-5, anak dapat mengurutkan bilangan 6-10, anak mampu menjodohkan lambang bilangan dengan jumlah benda yang ada, anak dapat mengkoreksi lambang bilangan yang salah dengan jumlah benda yang ada. Hal ini mengacu pada Kurikulum 2013 tahap perkembangan anak usia 5-6 tahun sebagai berikut yaitu mengelompokan benda berdasarkan fungsi, menunjukan aktivitas yang bersifat eksploratif, dan menyelidiki, menyusun perencanaan kegiatan yang akan dilakukan, mengenal sebab akibat tentang lingkungannya, menunjukan inisiatif dalam mmemilih tema permainan, memecahkan masalah sederhana dalam kehidupan sehari-hari, mengenal perbedaan berdasarkan ukuran (lebih dari, kurang dari, paling
. . .), mengelompokan benda berdasarkan warna, bentuk dan ukuran, mengenal pola, mengurutkan benda berdasarkan ukuran dari paling kecil ke paling besar atau sebaliknya, membilang 1-10, mencocokan bilangan dengan lambang bilangan, dan mengenal berbagai macam huruf vocal dan konsonan. Dalam penelitian ini peneliti mengambil dasar dalam pengembangan konsep bilangan sederhana berdasarkan Kurikulum 2013 diantaranya adalah memecahkan masalah sederhana dalam kehidupan sehari-hari, mengenal perbedaan berdasarkan ukuran (lebih dari, kurang dari, paling. . . . ), mengurutkan benda berdasarkan ukuran dari paling kecil ke paling besar atau sebaliknya, membilang, dan mencocokan bilangan dengan lambang bilangan. Jumlah anak yang diobservasi adalah 22 anak. Berdasarkan hasil observasi awal kondisi kemampuan penguasaan konsep bilangan dalam pembelajaran masih dirasa belum optimal hal ini dibuktikan dengan data hasil mewawancarai guru terhadap kondisi kemampuan penguasaan konsep bilangan anak di kelompok A Abu Bakar Sidiq, dan guru menjawab bahwa kondisi kemampuan penguasaan konsep bilangan di kelompok A Abu Bakar Sidiq ini sedikit sudah ada yang bisa hanya saja penyebutan angka dengan lambang bilangan masih kurang fasih, lalu penggunaan pembelajaran pun hanya dicoba diulang dengan benda yang ada disekitar tanpa ada media pembelajaran khusus. Selanjutnya, 
kemampuan penguasaan konsep bilangan dasar pada penelitian mengacu pada kurikulum 2013 dengan delapan sub indicator, diantaranya anak dapat menyebutkan bilangan bilangan 1-5, anak dapat menyebutkan bilangan 1-5 secara acak, anak dapat menyebutkan bilangan 6-10, anak dapat menyebutkan bilangan 1-6 secara acak, anak dapat mengurutkan bilangan 1-5, anak dapat mengurutkan bilangan 6-10, anak mampu menjodohkan lambang bilangan dengan jumlah benda yang ada, dan anak dapat mengoreksi lambang bilangan yang salah dengan jumlah benda yang ada. Adapun kendala dalam pembelajaran penguasaan konsep bilangan sederhana ini yakni dimana anakanak masih malu dalam hal mengungkapkan sesuatu sehingga guru sedikit kesulitan dalam memahami perkembangan anak tersebut. Adanya permasalahan tersebut jika dibiarkan akan menimbulkan ke masalah yang lain nya, bahkan menghabat pada pemahaman perkembangan kemampuan penguasaan konsep bilangan sederhana di tahap selanjutnya. Adapun tahap kemampuan konsep bilangan yang harus dicapai oleh anak menurut Sriningsih (2009, hlm.23) mengemukakan tiga tahapan terhadap pemahaman konsep bilangan: Tahap enaktif, pada tahap enaktif ini anak secara langsung terlibat dalam memanipulasi objek. a. Tahap Ikonik, pada tahap ikonik kegiatan yang dilakukan anak berhubungan dengan mental yang merupakan gambaran dari objekobjek yang dimanipulasinya. Anak-anak tidak langsung memanipulasi objek seperti pada tahap pertama.

b. Tahap Simbolik, pada tahap simbolik ini anak memanipulasi symbol-simbol atau lambanglambang tertentu. Anak tidak lagi terikat dengan objek-objek pada tahap sebelumnya.

Selain pentingnya tahapan kemampuan penguasaan konsep bilangan untuk anak, faktor terbesar penyebab kurangnya kemampuan penguasaan konsep bilangan di kelompok A pun terlihat ketika dimana anak malu dalam mengungkapkan sesuatu sehingga guru sulit melihat perkembangan kemampuan penguasaan konsep bilanga anak, dan penggunaan media yang hanya itu-itu saja menjadikan anak bosan dalam proses pembelajaran. Seperti yang dikatakan oleh Sudarmaji (2002, hlm. 25) faktor penyebab kurangnya kemampuan penguasaan konsep bilangan sederhana yaitu kelemahan pada proses penglihatan atau visual, kurang berfungsinya kesiapan otak dalam menerima informasi, sikap dan keadaan lingkungan yang tidak mendukung. Faktor dalam penggunaan media pun menjadikan penyebab pada kemampuan penguasaan konsep bilangan sederhana ini, karena penggunaan media sangat penting terhadap proses 
pembelajaran. Menurut Arsyad (2006, hlm. 16) pemakaian media pembelajaran dalam proses belajar mengajar itu sangat penting karena dapat membangkitkan keinginan dan minat baru, membangkitkan motivasi dan merangsang kegiatan belajar, dan bahkan membawa pengaruhpengaruh psikologi terhadap anak.

Berdasarkan hasil kondisi dilapangan tersebut maka peneliti menentukan upaya yang harus dilakukan dalam meningkatkan kemampuan penguasaan konsep bilangan sederhana anak usia dini dengan menerapkan penguanaan media pembelajaran berupa alat permainan edukatif. Upaya belajar sambil bermain dijadikan metode dalam pembelajaran penguasaan konsep bilangan nanti, seperti hal nya yang diungkapkan oleh Docket dan Fleer (2002, hlm.41) bahwa bermain merupakan kebutuhan bagi anak, karena melalui bermain anak akan memperoleh pengetahuan yang dapat mengembangkan kemampuan dirinya.

\section{Pelaksanaan Pembelajaran Penguasaan Konsep Bilangan Melalui Penggunaan Media Puzzel}

Pengguanaan media puzzel untuk meningkatkan kemampuan penguasaan konsep bilangan dalam penelitian ini dilaksanakan melalui dua siklus, dan setiap siklus terdiri dari dua tindakan yang terdiri dari perencanaan, tindakan, pelaksanaan, tindakan, pengamatan atau observasi dan refleksi. Kegiatan pembelajaran yaitu penggunaan media puzzel. dalam kegiatan ini anak diajak untuk mengembangkan kemampuan penguasaan konsep bilangan. Adapun jenis media pembelajaran menurut Eliyawati, C (2005, hlm. 113) adalah media audio, media visual dan media audio-visual. Media pembelajaran berupa APE puzzel merupakan jenis media visual, karena puzzel hanya dapat dilihat dan dapat dirasakan atau diraba, dengan tujuan untuk memberikan pengalaman yang konkrit kepada anak agar dapat dipahami dengan baik dan menjadi bekal bagi perkembangan anak ke tahap berikutnya. Penggunaan puzzle dilakukan kerena melihat ruang kelas yang kurang bermacamnya media pembelajaran sehingga kurang begitu kenal anak dengan angka dan jumlah benda. Puzzel adalah sebuah permainan untuk menyatukan pecahan kepingan untuk membentuk sebuah gambar atau tulisan yang telah ditentukan, selain itu puzzel memiliki keunggulan karena memiliki bermacam-macam warna sehingga menarik minat anak untuk belajar dan meningkatkan daya tahan anak dalam belajar menurut Indriana, D (2011, hlm. 23). Dengan begitu puzzel mampu mengembangkan kemampuan penguasaan konsep bilangan yang dimiliki anak. Penggunaan media puzzel sudah peneliti diskusikan dengan guru kelas. Adapun penggunaan penerapan media puzzel dalam meningkatkan kemampuan penguasaan konsep bilangan untuk anak akan menjadikan anak lebih senang dalam bermain 
sambil belajar, sama halnya yang diungkapkan Robert dalam Noorlaila (2010, hlm. 35) bahwa bermain ini sebagai kegiatan yang mempunyai nilai praktis, artinya bermain sebagai media untuk meningkatkan keterampilan dan kemampuan tertentu pada anak.

Dalam kegiatan meningkatkan penguasaan konsep bilangan melalui penggunaan media puzzel pertama-tama semua anak berkumpul terlebih dahulu di halaman sekolah untuk baris berbaris, pembacaan ikrar santri, mengulang hafalan bersama (surat-surat pendek, hadits dan bahasa arab). Setelah selesai anak-anak masuk ke kelasnya masing-masing. Kelompok A Abu Bakar Sidiq melanjutkan pembelajaran dengan praktik solat, berdoa, dan lagu-lagu yang berhubungan dengan pembelajaran. Lagu yang dipilih adalah lagu angkaangka, nama-nama hari, nama-nama bulan. Kegiatan selanjutnya adalah guru menyampaikan materi pembelajaran, yaitu mengenal bilangan menggunakan puzzel. guru bersama anak menyebutkan bersamasama bilangan 1-10, berhitung menggunakan jari dan menghubungkan lambang bilangan dengan benda melalui media puzzel. setiap anak memiliki kesempatan yang sama untuk berlatih mengembangkan kemampuan penguasaan konsep bilangan. Terjadi respon yang sangat antusias dalam pembelajaran ini. Namun, pada siklus I kemampuan anak belum berkembang secara sesuai dengan apa yang diharapkan, dikarenakan belum mencapainya target pengembangan anak kelompok A Abu Bakar Sidiq. Dengan berlatih terus menggunakan media puzzel maka ada peningkatan kemampuan penguasaan konsep bilangan pada siklus selanjutnya yaitu siklus II. Karena penguasaan konsep bilangan sudah mencapai $83 \%$ maka peneliti putuskan untuk mengakhiri penelitian hingga siklus II.

Pembelajaran dimulai dari siklus I yaitu pengenalan bilangan. Adapun pembelajaran dalam siklus I ini terdiri dari dua pertemuan. Pembelajaran siklus I tindakan I dimulai dengan tiga sub indikator yaitu anak dapat menyebutkan bilangan 1-5, anak dapat menyebutkan bilangan 6-10 dan anak dapat mengetahui jumlah banyaknya benda. Penerapan penggunaan media pembelajaran berupa APE Puzzel pada siklus I tindakan I awalnya membuat anak senang, akan tetapi karena kemampuan dasar yang anak miliki belum berkempang secara optimal sehingga masih ada anak yang kebingungan dan terbalik dalam meyebutkan angka, seperti 6 dan 9 . Hal ini terjadi karena pembelajaran guru lebih sering menghafal bukan memahami konsep. Sehingga pada tindakan selanjutnya diberi arahan untuk menggarisi angka 6 dan 9 menjadi $\underline{6}$ dan $\underline{9}$. Selanjutnya pelaksanaan siklus I tindakan II. Pada siklus I tindakan II ini menggembangkan dua sub indicator yaitu anak dapat mengurutkan bilangan 1-5 dan anak dapat mengurutkan bilangan 6-10. 
Penggunaan media pada siklus I di tindakan I dan II ini menjadi peran penting dalam meningkatkan kemampuan penguasaan konsep bilangan sederhana karena akan memudahkan anak dalam belajar, hal tersebut sama seperti yang diungkapkan Benni A (dalam Musfiqon, 2012, hlm. 33) bahwa penggunaan media pembelajaran dapat membantu memudahkan anak dalam proses pembelajaran, memberikan pengalaman lebih nyata, menarik perhatian anak agar tidak mudah bosan dalam proses pembelajaran.

Selanjutnya siklus II. Kegiatan pada siklus II sama seperti siklus I yaitu terdiri dari II tindakan. Siklus II tindakan I ini diawali dengan pengenalan media puzzel. Sub indikator yang dicapai adalah anak dapat menyebutkan bilangan 1-5, anak dapat menyebutkan 6-10 dan anak dapat mengetahui jumlah benda. Pengenalan puzzel dilakukan dengan metode demonstrasi yaitu guru bersama-sama dengan anak-anak menghitung benda dari 1-10, dan guru mengenalkan angka dari 1-10. Lalu guru mencontohkan untuk menghubungkan bilangan dengan benda, lalu anak pun bergantian mengikuti menghubungkan benda dengan angka. Dan yang terakhir pelaksanaan siklus II tindakan II, dengan sub indikator anak dapat mengurutkan bilangan 1-5 dan anak dapat mengurutkan bilangan 6-10. Kegiatan dilakukan dengan cara guru menyimpan secara acak angka dengan benda lalu anak diminta untuk mengkoreksi aapakan ada yang salah dalam menjodohkan antara angka dan benda. Hal ini dilakukan untuk mengetahui pemahaman anak dalam menguasai konsep bilangan sederhana. Hasil pada kemampuan penguasaan konsep bilangan sederhana di siklus II ini dapat dikatakan sama sesuai dengan harapan guru dimana terdapat peningkatan dari siklus sebelumnya dengan menerapkan media pembelajaran APE puzzel. Karena dengan menerapkan media pembelajaran APE puzzel anak merasa belajar sambil bermain dan merasa senang dalam melakukan kegiatan serta mendapat manfaat yang baik. Seperti yang dikatakan menurut Yuriastien (2009, hlm. 22) terdapat sembilan manfaat bermain bagi anak usia dini, yaitu: memahami diri sendiri dan mengembangkan harga diri, menemukan apa yang dapat mereka lakukan dan mengembangkan kepercayaan, melatih mental anak, meningkatkan daya kreativitas dan membebaskan anak dari stress, mengembangkan pola sosialisasi dan emosi anak, melatih motoric dan mengasah daya analisa anak, penyaluran bagi kebutihan dan keinginan anak, standar moral dan yang terakhir mengembangkan otak kanan anak. Selama kegiatan penelitian ini dilaksanakan penulis menghadapi hambatan diantaranya penyamaan jadwal dalam meneliti yang sulit karena adanya libur, peneliti harus melakukan pendekatan diri kepada anak-anak sehingga anak-anak tidak 
tidak menganggap peneliti sebagai orang asing, perumusan indikator yang harus dipenuhi oleh guru tidak dilaksanakan sepenuhnya dan waktu pembelajaran yang sebentar.

Penguasaan konsep bilangan erat kaitannya dengan perkembangan kognitif, karena penguasaan konsep bilangan termasuk aspek perkembangan kognitif. Perkembangan kognitif dapat diartikan sebagai kemampuan untuk mengerti sesuatu, yaitu mengerti menunjukan kemampuan untuk menangkap sifat, arti, atau keterangan mengenai sesuatu serta mempunyai gambaran yang jelas (Maslihah, 2005, hlm.10). adapun karateristik perkembangan kognitif anak usia 4-5 tahun adalah mengelompokan dan menunjukan benda berdasarkan bentuk, ukuran dan jenis, menyebutkan urutan bilangan 1-10, membilang dan menunjukan benda,mengenal konsep banyaksedikit, lebih-kurang, sama-tidak sama, menghubungkan lambang bilangan dengan benda, mengenal dan mengelompokan bentuk geometri,memecahkan masallah sederhana seperti mengerjakan maze, menyusun puzzel, mencari lokasi asal suara, dan mengenal konsep ruang, posisi dan ukuran secara sederhana (Wening, 2012, hlm. 162). Dengan begitu permainan puzzel ini dapat mengembangkan perkembangan kognitif anak. Terbukti dengan adanya penelitian ini yaitu meningkatnya kemampuan penguasaan konsep bilangan melalui penggunaan media puzzel.

\section{Peningkatan Penguasaan Konsep Bilangan Melalui Media Puzzel}

Hasil penelitian pada kemampuan penguasaan konsep bilangan menggunakan media puzzel di kelompok A Abu Bakar Sidiq RA Al-Kautsar Cimahi selama dua siklus, dengan masing-masing siklus dilakukan tindakan penulis menyimpulkan bahwa kemampuan penguasaan konsep bilangan sederhana mengalami peningkatan yang cukup signifikan atau cukup baik.

Berdasarkan hasil penelitian yang dilaksanakan menunjukan adanya peningkatan yang cukup baik pada kemampuan penguasaan konsep bilangan dari siklus I pertemuan I, siklus I pertemuan II, siklus II pertemuan I dan siklus II pertemuan II. Peningkatan kemampuan tersebut dapat dilihat pada saat mewawancara guru setelah diberikannya penggunaan media puzzel terhadap penguasaan konsep bilangan, dan guru pun mengatakan bahwa guru pernah memberikan pembelajaran mengenai konsep bilangan dan pernah menggunakan puzzel sebagai media pembelajaran, hanya saja penerapannya berbeda. Selanjutnya guru sangat senang karena pada kegiatan penguasaan konsep bilangan dengan menggunakan media puzzel ini menjadikan anak berantusias dalam pembelajaran. Hal tersebut dapat dilihat ketika pembelajaran belum dimulai anak-anak sering menggunakan puzzel untuk bermain. 
Dan dapat dilihat dari semakin bertambahnya anak yang memiliki tahap perkembangan baik (B) pada kondisi awal (pra-siklus) sebanyak 0\%, pada kondisi akhir siklus I 9\% dan akhir siklus II menjadi 77\%. Dan menurunnya anak yang memiliki tahap perkembangan cukup (C) pada kondisi awal (pra-siklus) sebanyak $27 \%$ dan pada akhir siklus I 68\% menjadi $23 \%$ di akhir siklus II. Serta menurunnya anak yang memiliki tahap perkembangan kurang (K) pada saat kondisi awal (pra-siklus) menunjukan $73 \%$, dan pada akhir siklus I 23\% menjadi $0 \%$ pada akhir siklus II.

Pada kemampuan penguasaan konsep bilangan ini, mengacu pada delapan sub indikator yang dibuat sesuai dengan kurikulum 2013. Delapan sub indikator tersebut diantaranya, anak dapat menyebutkan bilangan 1-5, anak dapat menyebutkan bilangan 15 secara acak, anak dapat menyebutkan bilangan 6-10, anak dapat menyebutkan bilangan 6-10 secara acak, anak dapat mengurutkan bilangan angka 1-5, anak dapat mengurutkan bilangan angka 6-10, anak mampu menjodohkan lambang bilangan dengan jumlah benda yang ada dan anak dapat mengkoreksi lambang bilangan yang salah dengan jumlah benda yang ada. Hal ini selaras dengan pendapat Nurjatmika bahwa bermain puzzel dapat meningkatkan kemampuan berfikir dan membuat anak menjadi konsentrasi serta dapat meningkatkan kemampuan mengetahui dan mengingat (Suryastini, A, 2014, hlm.6). melalui puzzel maka anak akan mampu membangun wawasannya sendiri. Puzzel digunakan untuk menarik minat anak dalam belajar. Dengan menggunakan puzzzel maka anak tidak merasa bahwa sedang belajar, sesuai dengan hakikat pembelajaran yaitu belajar sambil bermain dan bermain sambil belajar.

Di siklus I dan II sesudah diberikan penerapan penggunaan media puzzel terhadap kemampuan penguasaan konsep bilangan dapat dilakukan oleh anak dengan benar sesuai harapan guru, dimana anak dapat menyebutkan bilangan angka serta mengurutkan bilangan angka dengan menggunakan penerapan media puzzel. Selanjutnya penerapan media puzzel menurut Suciaty (2010, hlm.78) bermanfaat untuk mengasah otak, melatih koordinasi mata dan tangan, melatih nalar, melatih kesabaran dan sebagai pengetahuan.

Hasil meningkatnya aspek perkembangan kemampuan penguasaan konsep bilangan sederhana yang terdapat pada penerapan pelaksanaan penggunaan media puzzel. Sebelum peneliti melihat hasil dari peningkatan tersebut, Adapun yang dikatakan guru dalam melakukan kegiatan penguasaan konsep bilangan sederhana menggunakan media puzzel berkendala dalam segi kepingan puzzel yang mudah lepas, terlalu kecil untuk kelompok Adan bahan yang digunakan kurang ekonomis. Adapun kelebihan dari 
media puzzel adalah anak menjadi lebih cepat mengingat letak atau urutan banyak, benda dan dapat membantu mengembangkan aspek perkembangan yang lainnya, misalnya dengan meraba maka anak dapat mengembangkan kemampuan motorik dan sosial emosional anak.

Hasil tersebut dapat dikatakan meningkat pada penerapan penggunaan media pembelajaran dalam meningkatkan kemampuan penguasaan konsep bilangan sederhana. Penelitian ini sama hal nya dengan penelitian sebelumnya yang dilakukan oleh peneliti lain Nurmi (2015) akan tetapi berbeda aspek. Nurmi meneliti mengenai penerapan permainan leg puzzle untuk meningkatkan kemampuan berhitung permulaan pada anak di RA Nurinsani Tamarunang Kabupaten Gowa tahun 2015, menunjukan bahwa perkembangan kemampuan berhitung pemula meningkat setelah menerapkan mendapatkan hasil yang meningkat. Sehingga dapat dikatakan bahwa penerapan media pembelajaran APE puzzel dapat meningkatkan kemampuan penguasaan konsep bilangan sederhana anak di kelompok A Abu Bakar Sidiq RA Al-Kautsar.

\section{KESIMPULAN}

Berdasarkan hasil penelitian tentang meningkatkan kemampuan penguasaan konsep bilangan anak usia dini melalui penggunaan media puzzel di kelompok A Abu Bakar Asidiq Cimahi Jl. Kebon Jeruk No. 261 Kelurahan Cibeureum
Kecamatan Cimahi Selatan Kota Cimahi, dapat disimpulkan bahwa:

$$
\text { Kondisi kemampuan }
$$

penguasaan konsep bilangan di kelompok A Abu Bakar Sidiq RA AlKautsar Cimahi sebelum diberi perlakuan (pra-siklus) awalnya peneliti mewawancarai guru terlebih dahulu untuk mengetahui kondisi kemampuan penguasaan konsep bilangan sederhana serta kendala apa saja yang dialami guru dalam aspek kemampuan tersebut. Lalu kondisi awal ini mengacu pada delapan indikator yang terdapat pada kurikulum 2013. Selain itu, adapun hasil yang didapat pada prasiklus ini yaitu $0 \%$ anak berada pada kategori baik, 27\% anak berada pada kategori kurang dan $73 \%$ anak berada pada kategori kurang. Jika permasalahan ini tidak diperbaiki, maka akan berdampak buru bagi anak untuk ke tahap perkembangan kemampuan penguasaan konsep bilangan sederhana selanjutnya. Dampak tersebut meliputi menyebabkan anak mempunyai masalah dalam kehidupan sehari-hari, seperti anak kan kebingungan dalam konsep waktu dan ruang, anak akan sulit mengenal bilangan, anak akan sulit memahami pengenalan aljabar, anak akan sulit memahami pengukuran, anak akan sulit memahami pola, anak akan sulit memahami geometrid an anak akan sulit memahami analisis data.

Pelaksanaan penggunaan media pembelajaran berupa alat permainan edukatif puzzel sebagai upaya mengembangkan penguasaan 
konsep bilangan sederhana dilakukan dengan dua siklus dan masing-masing siklus diberikan dua tindakan. Pada pelaksanaan siklus I media yang digunakan adalah kepingan puzzel yang menyerupai kartu angka, awalnya anak kebingungan dalam penyebutan bilangan karena kurang sempurnanya strategi yang dibuat. Sehingga anak kebingungan dalam mengurutkan bilangan. Pada siklus II ini, penereapan penggunaan media pembelajaran disempurnakan lagi menggunakan media puzzel sehingga anak dapat memahami pembelajaran dengan benar.

Kemampuan penguasaan konsep bilangan anak kelompok A Abu Bakar Sidiq RA Al-Kautsar setelah digunakan penerapan penggunaan media puzzel (pasca-siklus) menunjukan hasil bahwa terdapat peningkatan pada kemampuan penguasaan konsep bilangan yang dilihat dari kegiatan anak dari siklus I sampai dengan siklus II. Hasil tersebut dapat dilihat dari hasil persentase kategori kurang $(\mathrm{K})$ pada akhir siklus I 23\% menjadi 0\% pada akhir siklus II, Untuk kategori cukup (C) pada akhir siklus I 68\% menjadi $23 \%$ pada akhir siklus II dan untuk kategori baik (B) pada akhir siklus I 9\% menjadi $77 \%$ pada akhir siklus II. Dengan begitu dapat dikategorikan bahwa penerapan penggunaan media puzzel dapat meningkatkan kemampuan penguasaan konsep bilangan anak usia dini di kelompok A Abu Bakar Sidiq RA Al-Kautsar.

\section{DAFTAR PUSTAKA}

Aqil, dkk. (2009). Media Pembelajaran. Jakarta: Rineka Cipta

Arsyad. (2006). Media Pembelajaran. Jakarta: Rineka Cipta

Docket \&Fleer. (2002). Play and Pedagogy in Early Children. American: American Boks

Eliyawati, C, (2005). Pemilihan dan Pengembangan Sumber Belajar untuk Anak Usia Dini. Jakarta: Depdiknas

Indriana, D (2011). Ragam Alat Bantuan Media Pengajaran. Yogyakarta: Diva Press.

Kadijah. (2016). Pengembangan Kognitif Anak Usia Dini. Medan: Perdana Publishing

Kustini. (2010). Meningkatkan Pemahaman Konsep Bilangan Anak Usia Dini Melalui Kegiatan Bermain Dengan Media Kartu Angka Di TK Pertiwi Rejosari. Semarang

Masitoh, dkk. (2005). Pendekatan Belajar Aktif di Taman Kanak-kanak. Jakarta: Departemen Pendidikan Nasional, Direktorat Jendral Pendidikan Tinggi, Direktorat Pembinaan Pendidikan Tenaga Kependidikan dan Ketenagaan Perguruan Tinggi. 